\title{
Mycobacterium leprae in the periodontium, saliva and skin smears of leprosy patients
}

\author{
Mycobacterium leprae no periodonto, saliva e raspados \\ intradérmicos de sujeitos com hanseníase
}

\begin{abstract}
Purpose: To verify the presence of $M$. leprae in the periodontium, saliva and skin slit smears of leprosy patients. To correlate bacteriological and molecular findings with clinical data and compare laboratory techniques.

Methods: A cross-sectional study was designed to use bacteriological (baciloscopy) and molecular (PCR) parameters to detect $M$. leprae in exudates of the gingival sulcus/periodontium pocket, saliva and skin slit smears from multiple clinical forms of leprosy patients without previous treatment.

Results: The study included 48 leprosy patients with 15 multibacillary (MB) cases and 33 paucibacillary (PB) cases. The diagnosis of $M B$ was confirmed through bacteriological examination and PCR results from skin slit smears. A total of 16 (48.5\%) PB patients were PCR positive only. Four PB patients with negative PCR skin smears were PCR positive for the periodontium and saliva, with 2 cases and 1 case, respectively. No periodontium or saliva samples had positive bacteriological results.

Conclusion: There was no correlation between periodontal disease and the presence of M. leprae. Bacteriological examination did not prove to be an efficient technique for the analysis of saliva and periodontium samples. PCR analysis of skin smears was more efficient at diagnosing PB patients than bacteriological examination. PCR positive results for the detection of $M$. leprae in PB patients can be increased by collecting slit skin smears, periodontium and saliva samples.
\end{abstract}

Key words: Mycobacterium leprae; skin smears; PCR; periodontium; saliva; bacteriological examination

\section{Resumo}

Objetivo: verificar através da baciloscopia e da reação em cadeia da polimerase (PCR) a presença do $M$. leprae no periodonto, saliva e raspados intradérmicos de pacientes com hanseníase.

Metodologia: Realizou-se um estudo transversal do tipo detecção de casos numa instituição referência de hanseníase no Amazonas.

Resultados: Foram avaliados 48 pacientes, sendo 15 multibacilares (MB) e 33 paucibacilares (PB). Os pacientes MB tiveram o diagnóstico confirmado pela baciloscopia e PCR dos raspados intradérmicos, enquanto que $16(48,5 \%)$ dos PB foram positivos apenas na PCR. Quatro pacientes $\mathrm{PB}$ negativos na PCR de raspados intradérmicos foram positivos no periodonto e na saliva, 1 positivo na saliva e 2 no periodonto. Nenhuma amostra do periodonto e da saliva foi positiva na baciloscopia.

Conclusão: Não houve relação entre a doença periodontal e a presença do $M$. leprae; a baciloscopia não mostrou ser uma técnica eficiente para análise da saliva e periodonto; a técnica de PCR de raspado dérmico mostrou ser um método mais eficaz no diagnóstico dos PB do que a baciloscopia; a positividade da PCR para detecção do M. leprae nos PB pode ser aumentada coletando raspado intradérmico, periodonto e saliva.

Key words: Mycobacterium leprae; hanseníase; PCR; periodonto; saliva; exame bacteriológico

\author{
Ligia Fernandes Abdalla a \\ Joáo Hugo Abdalla Santos b \\ Carolina Souza Cunha Colladoc \\ Maria da Graça Souza Cunha d \\ Felipe Gomes Naveca ${ }^{\text {e }}$
}

a Masters program in Tropical Pathology, Universidade Federal do Amazonas (UFAM), Manaus, AM, Brazil

${ }^{b}$ Residency in Infectious Diseases, Fundação de Medicina Tropical, Manaus, AM, Brazil

cMedical School, Universidade Nilton Lins, Manaus, AM, Brazil

d Graduate Program in Medical Sciences, Fundação Alfredo da Matta (FUAM), Manaus, AM, Brazil e Instituto Leônidas e Maria Deane, Fiocruz/AM, Manaus, AM, Brazil

\author{
Correspondence: \\ Ligia Fernandes Abdalla \\ Rua Júlio Verne, 121, Bloco C, apto 303 \\ Bairro Aleixo \\ Manaus, AM - Brasil \\ 69060-770, \\ E-mail: ligia_abdalla@yahoo.com.br
}

Received: June 20, 2009

Accepted: February 9, 2010

Conflict of Interest Statement: The authors state that there are no financial and personal conflicts of interest that could have inappropriately influenced their work.

Copyright: (C) 2010 Abdalla et al.; licensee EDIPUCRS. This is an Open Access article distributed under the terms of the Creative Commons AttributionNoncommercial-No Derivative Works 3.0 Unported License. 


\section{Introduction}

Leprosy is an infectious disease that mainly affects the skin, peripheral nerves and mucosa, and it is caused by a mycobacterium called Mycobacterium leprae (1). It is transmitted through secretions (semen, saliva, sweat or tears) of patients with infectious forms of the disease or by direct contact with the skin through open wounds (2).

Leprosy is a clinical diagnosis, which is confirmed through baciloscopy of skin slit smears (gold standard) and biopsy. Leprosy has been classified according to Ridley and Jopling (3) with the initial form of the disease classified as indeterminate (I), which may cure spontaneously or evolve to a broad spectrum of clinical manifestations. These clinical manifestations reflect different cellular immune responses by the host to $M$. leprae. Accordingly, it may remain limited, tuberculoid pole (T), evolve to disseminated forms, lepromatous pole (L), or take an intermediate position between these two poles, borderline (B). Depending on its proximity to one or another pole, the borderline group is subdivided into borderline tuberculoid (BT), borderline borderline (BB) and borderline lepromatous (BL). In recent years, the World Health Organization (WHO) (4) has encouraged endemic countries to classify patients according to the number of skin lesions. These groups include paucibacillary $(\mathrm{PB})$ patients with one to five lesions and multibacillary (MB) patients with more than five lesions. Periodontal disease in leprosy, especially the Lepromatous form, is relatively common and is characterized by frequent gingival bleeding at the slightest touch, papillary hypertrophy of the gums, tooth loss and areas of hypoesthesia at the border of alveolus mucosa. Moreover, one can see a direct relationship between the time period from the initial leprosy diagnosis and the development of chronic inflammatory periodontal disease (5).

Despite literature reporting the involvement of periodontium during the course of this disease, few reports extend beyond clinical aspects such as gingival health and plaque index. Notably, no studies have examined M. leprae in the periodontium. Considering that leprosy patients are often from lower socio-economic classes, this population may also be expected to have deficiencies in oral hygiene. Hence, research addressing the occurrence of $M$. leprae in the periodontium is the first step to see if there is a direct relationship between periodontal disease and leprosy.

Due to a lack of publications in this area and leprosy's public health concerns, this study utilized bacteriological (baciloscopy) and molecular (PCR) parameters to determine the presence of $M$. leprae in gingival sulcus exudates, skin slit smears as well as periodontium and saliva samples from leprosy patients without previous treatment and with different clinical forms of the disease. This study aimed to correlate bacteriological and molecular findings with clinical data and to compare these two laboratory techniques.

\section{Methodology}

This study included 48 individuals of both sexes who were between 18 and 65 years old. Leprosy had been determined by clinical and/or laboratory analyses and these patients had received no previous treatment. This study was approved by the Ethics Committee of the Fundação de Dermatologia Tropical e Venereologia Alfredo da Matta, protocol number FR-176358, CAAE-0001.0.266.115-08.

\section{Data Collection}

Demographic data and the following information relevant to the health of the periodontium were collected from each patient through a questionnaire: smoking history, use of distilled drinks, gum bleeding, mouth breathing, halitosis, bruxism and dental hygiene history. Relevant clinical information such as the classification of leprosy, number of skin lesions and duration of disease were collected from patient medical files.

\section{Periodontal Exam}

The periodontal exam was performed on all of the teeth using a dental mirror and manual millimeter periodontal probe, which was based on a model used by the University of North Carolina Dental School (Chapel Hill, NC, USA). The clinical parameters evaluated included probing depth, clinical insertion level and gingival recession, gingival index, bleeding and plaque index. Periodontal disease (PD) was classified according to the WS index (6), which used the following criteria: $\mathrm{P} 0$, gingival health; $\mathrm{P} 1$, mild periodontitis; P2, moderate periodontitis; P3, advanced periodontitis; and $\mathrm{P} 4$ severe periodontitis. To evaluate the association between periodontal conditions and other variables, we used the criteria of López et al. (7), which established a $3 \mathrm{~mm}$ insertion loss as the minimum to be considered as diseased. Group A was composed of patients classified as P2, P3 and P4. Group B was composed of patients classified as P0 and $\mathrm{P} 1$.

\section{Collection of samples}

Skin slit smears, saliva samples and gingival exudates were collected from each patient. The skin slit smears were obtained by inducing local ischemia followed by a superficial cut with a sterile scalpel blade, which was performed according to World Health Organization (WHO) standards (4). Smears were then placed onto a microscope slide. The material used for PCR was obtained by pipetting the collected samples directly from the scalpel blade, which was placed into a microtube containing $400 \mathrm{~mL}$ of saline. The saliva for PCR analysis was obtained after chewing a piece of sterilized latex tube. The saliva produced during the first $30 \mathrm{~s}$ was swallowed and subsequent saliva was collected in disposable plastic containers. The saliva (approximately $400 \mu \mathrm{L}$ ) was transferred by pipette to a $1.5 \mathrm{ml}$ microtube and kept at $-20^{\circ} \mathrm{C}$ until extraction. For baciloscopy, $25 \mu \mathrm{L}$ of saliva was pipetted and placed on a microscope slide. 
The collection of gingival vestibular and lingual sulcus exudates from all individuals were performed using a Gracey Mine-Five 5/6 periodontal curette (HU-FRIEDY) and placed into a $1.5 \mathrm{~mL}$ microtube containing $400 \mu \mathrm{L}$ of saline for PCR. The microtubes were stored at $-20^{\circ} \mathrm{C}$ until DNA extraction. Exudates were also placed onto microscope slides for baciloscopy analysis.

In order to avoid the presence of DNA in the curette used for PCR sample collection, curettes were washed, sterilized in an autoclave, incubated in 5\% sodium hypochlorite for $1 \mathrm{~min}$ and placed under UV light for $15 \mathrm{~min}$. Control PCR assays were performed in curettes with similar latex tubes used for sample collection.

\section{DNA extraction}

An aliquot of $200 \mu \mathrm{L}$ of each sample was subjected to proteinase $\mathrm{K}$ digestion (Invitrogen, Carlsbad, CA, USA) as described by Stefani et al. with some modifications (8). Samples were incubated for $48 \mathrm{~h}$ at $60^{\circ} \mathrm{C}$ with $7.5 \mu \mathrm{L}$ of proteinase $\mathrm{K}(300 \mu \mathrm{g} / \mathrm{ml})$ in $42.5 \mu \mathrm{L}$ of sample buffer containing $100 \mathrm{mM}$ Tris- $\mathrm{HCl}(\mathrm{pH} 7.4), 150 \mathrm{mM}$ of $\mathrm{NaCl}$ and 10 mM EDTA (pH 8.0) (Invitrogen, Carlsbad, CA, USA). Subsequently, DNA extraction was performed according to the phenol-chloroform method (Invitrogen, Carlsbad, CA, USA). The DNA from each sample was precipitated with $500 \mu \mathrm{L}$ of isopropanol (Vetec, Rio de Janeiro, Brazil), washed with $500 \mu \mathrm{L}$ of $70 \%$ ethanol, dried at room temperature and suspended in $200 \mu \mathrm{L}$ of distilled water free of nucleases.

\section{Polymerase Chain Reaction for the detection of M. leprae DNA}

Each PCR reaction contained sense and antisense primers $(0.3 \mu \mathrm{M})$ for the human beta-actin gene and for the $85 \mathrm{~A}-\mathrm{C}$ intergenic region of the $M$. leprae genome (Invitrogen, São Paulo, SP, Brazil). The reaction contained $23 \mu \mathrm{L}$ of Platinum PCR Supermix (Invitrogen, São Paulo) and $3 \mu \mathrm{L}$ of the extracted sample. The primers for the beta-actin gene amplified a region between positions 342-361 (bact-1a, 5'-TCTACAATGAGCTGCGTGTG-3') and 736-754 (bact1b, 5'-CATCTCTTGCTCGAAGTCC-3') of the human gene, thereby producing an amplicon of 413 base pairs (bp) (9). This amplicon was used as a positive control for all subsequent PCR assays. The primers for $85 \mathrm{~A}-\mathrm{C}$ amplified the intergenic region of $M$. leprae between the $f b p A$ and $f b p C$ genes (sense, 5'-ATACTGTTCACGCAGCATCG-3' and antisense, 5'-GTTGAAGGCATCAAGCAGGT-3'), which produced a $250 \mathrm{bp}$ amplicon (10). The program used two amplification stages with an initial incubation period at $94^{\circ} \mathrm{C}$ ( $\left.3 \mathrm{~min}\right)$. The first amplification phase was 10 cycles of $94^{\circ} \mathrm{C}(30 \mathrm{~s}), 60^{\circ} \mathrm{C}(45 \mathrm{~s})$ and $72^{\circ} \mathrm{C}(30 \mathrm{~s})$. The second phase was 35 cycles of $94^{\circ} \mathrm{C}(30 \mathrm{~s}), 56^{\circ} \mathrm{C}(45 \mathrm{~s})$ and $72^{\circ} \mathrm{C}(30 \mathrm{~s})$, which was followed by a final extension at $72^{\circ} \mathrm{C}$ (7 min). Results were analyzed according to the presence or absence of amplicons visualized as bands on a $1.5 \%$ agarose gel (Invitrogen, Carlsbad, CA, USA) that was stained with Syber Safe (Invitrogen, Carlsbad, CA,
USA) according to the manufacturer's recommendations. The sizes of the beta-actin bands and the M. leprae genome were compared to a $100 \mathrm{bp}$ standard molecular weight ladder (Invitrogen, Carlsbad, CA, USA).

\section{Positive and negative controls}

For each PCR reaction carried out, a negative and positive control were added. The negative control contained only primers and the PCR mix. The positive control for M. leprae was performed using a skin slit smear sample taken from a multibacillary leprosy patient.

\section{Baciloscopy}

The Kinyoun staining method was used according to the protocol recommended by David et al. (11). Readings were done with an optic microscope under an immersion objective at a magnification of $1,000 \mathrm{X}$.

A bacillary index (BI) was used to obtain the results, which ranged from 0 to +6 depending on the number of bacilli visualized in each microscopic field (4).

\section{Statistical analysis}

Data were analyzed using a two-dimensional analysis of qualitative variables. The analysis of associations utilized contingency tables and Fisher's exact test. MINITAB (version 14) and R software (version 2.7.2) were used. The odds of occurrence and the overall probability of success were outcome measures.

\section{Results}

Among the 48 patients examined, 32 were male (66.7\%), and $16(48.5 \%)$ were female, with a combined mean age of 39.12 years old. When demographic data were related to periodontal disease (PD), age and degree of education demonstrated a statistically significant association $(P<0.05)$. In regard to periodontal disease, $20(41.67 \%)$ patients were classified as P0 to P1 (group A) and the other 28 were P2 to $\mathrm{P} 4$ (group B), which corresponded to a $58.33 \%$ overall prevalence of moderate to severe PD.

Table 1 shows the relationship between the classification of leprosy and the development of periodontal disease, which indicates that there was no statistically significant association. Also, no association was observed between tobacco/alcohol consumption and the presence of PD. However, there was a direct relationship between both gingival bleeding upon probing and the presence of dental plaque with the classification of periodontal disease $(P<0.001)$.

When oral hygiene variables (number of daily brushings, halitosis, presence of bleeding during brushing, flossing, use of mouthwash, mouth breathing and bruxism) were related to the presence of $\mathrm{PD}$, only mouth breath, the use of dental floss and the number of daily brushings were statistically significant $(P<0.05)$.

According to PCR results, all $15 \mathrm{MB}$ patients had positive results for their skin slit smears; however, only 2 patients had positive results for their periodontium, and 2 patients 
had positive saliva results. Of the 33 paucibacillary patients, $16(48.5 \%)$ had PCR positive skin slit smears. Among those 16 patients, 10 were positive for the skin slit smear only, 2 were saliva positive, 2 were periodontium positive, and 2 were both saliva and periodontium positive (Table 2).

There was no statistical relationship between periodontal disease and the presence of $M$. leprae in gingival sulcus exudates or in the saliva. Among the 12 patients with positive PCR results for $M$. leprae in the periodontium, 5 were included in group B, and the others were included in group A. Among the 10 patients with positive PCR results in the saliva, 4 belonged to group B, and the other 6 belonged to group A. All negative M. leprae PCR samples showed positive results for beta-actin, thereby confirming the DNA extraction effectiveness (Table 3 ).

Regarding the baciloscopy results, all multibacillary patients were positive in their skin slit smears; however, the paucibacillary patients were all negative. All periodontal and saliva samples collected for baciloscopy yielded negative results for microscopic examination of bacilli.

\section{Discussion}

It is interesting to note that although leprosy has existed for millennia, the clinical and laboratory diagnosis of this disease remain challenging. In this aspect, molecular biology techniques have had a significant clinical contribution towards treating this disease. Specifically, modern techniques have allowed researchers to identify the etiology of this disease with a higher sensitivity and in a shorter period of time. PCR is a method that has revolutionized the diagnosis of leprosy because it has a high sensitivity and specificity for the detection of $M$. leprae (12). The positive result among paucibacillary patients for $M$. leprae in skin slit smears by the PCR technique seems low but is relatively high when compared to standard smears that are always negative in these patients. In the literature, one can find data that are similar to this study. Previous studies have reported similarly small amounts of $M$. leprae DNA in paucibacillary patients, which ends up being inhibited by the presence of large amounts of human DNA in the samples (13).

Table 1. Relationship between leprosy classification and the development of periodontal disease.

\begin{tabular}{|c|c|c|c|c|c|}
\hline \multirow{2}{*}{ Leprosy } & \multirow{2}{*}{ Category } & \multicolumn{2}{|c|}{ Periodontal Classification } & \multirow{2}{*}{ Total } & \multirow{2}{*}{$\mathrm{P}^{*}$} \\
\hline & & Group A & Group B & & \\
\hline \multirow[t]{4}{*}{ Ridley and Jopling classification } & Undetermined & 4 & 4 & 8 & \multirow{4}{*}{0.391} \\
\hline & Tuberculoid & 7 & 3 & 10 & \\
\hline & Borderline & 10 & 11 & 21 & \\
\hline & Lepromatous & 7 & 2 & 9 & \\
\hline \multirow[t]{2}{*}{ Operational Classification } & $\mathrm{PB}$ & 20 & 13 & 33 & \multirow{2}{*}{0.755} \\
\hline & $M B$ & 8 & 7 & 15 & \\
\hline
\end{tabular}

* significance probability for Fisher exact test.

Table 2. PCR results in relation to the Leprosy Operational Classification.

\begin{tabular}{|c|c|c|c|c|c|}
\hline \multirow{2}{*}{ Variable } & \multirow{2}{*}{ Category } & \multicolumn{2}{|c|}{ Leprosy Classification } & \multirow{2}{*}{ Total } & \multirow{2}{*}{$\mathrm{P}^{*}$} \\
\hline & & MB & PB & & \\
\hline \multirow[t]{2}{*}{ Skin smear PCR } & Negative & 0 & 17 & 17 & \multirow{2}{*}{$<0.001$} \\
\hline & Positive & 15 & 16 & 31 & \\
\hline \multirow[t]{2}{*}{ Saliva PCR } & Negative & 13 & 25 & 38 & \multirow{2}{*}{0.472} \\
\hline & Positive & 2 & 8 & 10 & \\
\hline \multirow[t]{2}{*}{ Periodontium PCR } & Negative & 13 & 23 & 36 & \multirow{2}{*}{0.292} \\
\hline & Positive & 2 & 10 & 12 & \\
\hline
\end{tabular}

* significance probability for Fisher exact test.

Table 3. Relationship between the presence of M. leprae and periodontal classification.

\begin{tabular}{|c|c|c|c|c|c|}
\hline \multirow{2}{*}{ M. leprae } & \multirow{2}{*}{ Category } & \multicolumn{2}{|c|}{ Periodontal Classification } & \multirow{2}{*}{ Total } & \multirow{2}{*}{$\mathrm{p}^{*}$} \\
\hline & & Group A & Group B & & \\
\hline \multirow[t]{2}{*}{ Skin smear PCR } & Negative & 9 & 8 & 17 & \multirow{2}{*}{0.760} \\
\hline & Positive & 19 & 12 & 31 & \\
\hline \multirow[t]{2}{*}{ Saliva PCR } & Negative & 22 & 16 & 38 & \multirow{2}{*}{0.999} \\
\hline & Positive & 6 & 4 & 10 & \\
\hline \multirow[t]{2}{*}{ Periodontium PCR } & Negative & 21 & 15 & 36 & \multirow{2}{*}{0.999} \\
\hline & Positive & 7 & 5 & 12 & \\
\hline
\end{tabular}

* significance probability for Fisher exact test. 
Another typical problem occurs during $M$. leprae DNA extraction, which is primarily caused by the difficulty of breaking the bacterial cell wall. For this reason, better results were obtained when we increased the digestion time with proteinase $\mathrm{K}$ to $48 \mathrm{hrs}$ instead of the initial $16 \mathrm{hrs}$ (overnight) tested (data not shown).

An interesting result obtained from this study was that the PCR positive results for $M$. leprae in the periodontium and saliva samples were higher in paucibacillary patients than in multibacillary patients, which could not be explained. Another important result was that 4 paucibacillary patients were negative in the skin slit smear but had positive periodontium and saliva samples. Specifically, 1 patient was only saliva positive, and 2 patients were exclusively periodontium positive. Based on these results, we propose that PCR results for the $M$. leprae diagnosis in paucibacillary patients can be enhanced if intradermic, periodontium and saliva smears are collected and all are included in the same reaction. In this case, the number of patients with positive results would increase from $16(48.5 \%)$ to $23(69.7 \%)$.

With amendments to the protocol originally described by Martinez et al. (14), which included 10 PCR cycles with a higher hybridization temperature $\left(60^{\circ} \mathrm{C}\right)$ that were followed by 35 cycles at $55^{\circ} \mathrm{C}$, we also included the detection of an endogenous control (beta-actin) in the same PCR. These changes increased the reliability of the test by minimizing the possibility of false-negative results due to PCR inhibition from human DNA.

Since 1976, there have been several reports showing a direct relationship between periodontal disease and leprosy (15-17). Brazil et al. (18) stated that modifications in the oral cavity of leprosy patients were directly related to the form of the disease; however, this assertion was not supported by our study. Our results demonstrated that there was no statistically significant relationship between the number of clinically visible skin lesions and periodontal disease.

Scollard and Skinsnes (19) also diagnosed periodontium bone loss and gum disease in leprosy patients. According to Brand (20), these changes could be due to reactive bone alterations, chronic inflammation, neutrophil infiltration and decreases in local temperature. In addition, one might assume that the difficulties resulting from a claw-hand deformity would have a negative influence on proper oral hygiene; hence, these individual would be expected to have a higher prevalence of periodontal disease. However, this relationship could not be verified because there were no such cases in the present study.

Interestingly, both of these diseases have clinical presentations that are related to distinct immune patterns, which alter the cell mediated immune response when etiological agents are present. Although M. leprae has not been reported to cause periodontal disease, its presence in the gingival sulcus was detected in this study, thereby showing that this relationship may be true. For these cases, treatment with multidrug therapy should be sufficient for the regression of the patient's periodontal disease.

\section{Conclusions}

The prevalence of periodontal disease among leprosy patients ranged from moderate to severe; however, a direct relationship between the level of periodontal involvement and leprosy form and/or time of presentation was not established. Overall, there was no direct relationship between periodontal disease and the presence of $M$. leprae in gingival sulcus exudates or saliva samples. However, PCR positive results for M. leprae in periodontal and saliva samples were higher in paucibacillary patients than in multibacillary patients. This study reduced the possibility of false negative results by optimizing the DNA extraction method (i.e., a longer incubation period with proteinase $\mathrm{K}$ ) and by introducing a positive PCR control in a multiplex format.

After observing paucibacillary patients with negative PCR results for skin slit smears but positive results for periodontium and saliva samples, we recommend collecting and performing combined PCR analysis of skin slit smears, periodontal material and saliva samples. In addition, baciloscopy did not prove to be an efficient technique for the detection of M. Leprae in the saliva and periodontium.

\section{Acknowledgments}

This study received financial support from the Fundação de Amparo e Pesquisa no Amazonas (FAPEAM) through the RH-Amazônia program.

\section{References}

1. Neville BW, Damm DD, Allen CM, Bouquot JE. Infecções bacterianas - Lepra. In: Neville BW, Damm DD, Allen CM, Bouquot JE. Patologia oral e maxilofacial. Rio de Janeiro: Guanabara Koogan; 1998. p. 148-50.

2. Pinheiro MMO. A hanseníase em registro ativo no município de Passos, MG-Brasil [tese]. Franca (SP): Mestrado em Promoção da Saúde, Universidade de Franca; 2006.
3. Ridley DS, Jopling WH. A classification of leprosy for research purposes. Lepr Rev 1962;33:119-28.

4. Brasil. Ministério da Saúde. Guia de controle da hanseníase. Brasília: Centro de Documentação do Ministério da Saúde; 2002

5. Aarestrup FM, Aquino MA, Castro JM, Nascimento DN. Doença periodontal em hansenianos. Rev Periodontia 1995;4:191-3. 
6. Sallum W, Alves FA, Hipólito O, Lopes MA, Sallum EA. W.S.FOPUNICAMP: um novo método de diagnóstico periodontal. Rev Periodontia $2001 ; 4: 50-6$

7. López NJ, Smith PC, Gutierrez J. Higher risk of preterm birth and low birth weight in women with periodontal disease. J Dent Res 2002;81:58-63.

8. Stefani MM, Martelli CM, Gillis TP, Krahenbuhl JL. Brazilian Leprosy Study Group. In situ type 1 cytokine gene expression and mechanisms associated with early leprosy progression. J Infect Dis 2003; 188:1024-31.

9. Lin H, Huber R, Schlessinger D, Morin PJ. Frequent silencing of the GPC3 gene in ovarian cancer cell lines. Cancer Res 1999;59:807-10.

10. Rinke de Wit TF, Bekelie S, Osland A, Wieles B, Janson AA, Thole JE. The Mycobacterium leprae antigen 85 complex gene family: identification of the genes for the $85 \mathrm{~A}, 85 \mathrm{C}$, and related MPT5 1 proteins. Infect Immun 1993;61:3642-7.

11. David HL, Lévy-Frébault V, Thorel MF. Méthodes de Laboratoire pour Micobactériologie Clinique. Paris: Institut Pasteur; 1989.

12. Cole ST, Honore N, Eiglemeier K. Preliminary analysis of the genome sequence of Mycobacterium leprae. Lepr Rev 2000;71:162-7.
13. Martinez AN, Britto CFP, Nery JAC, Sampaio EP, Jardim MR, Sarno EN, Moraes MO. Evaluation of real-time and conventional PCR targeting complex 85 genes for detection of Mycobacterium leprae DNA in skin biopsy samples from patients diagnosed with leprosy. J Clin Microbiol 2006;44:3154-9.

14. Reichart P, Ananatasan T, Reznik G. Gingiva and periodontium in lepromatous leprosy. A clinical, radiological and microscopical study. J Periodontol 1976;47:455-60.

15. Girdhar BK, Desikan KV. A clinical study of the mouth in untreated lepromatous patients. Lepr Rev 1979;50:25-35.

16. Aarestrup FM, Aquino MA, Castro JM. Doença periodontal em hansenianos. Rev Periodontia 1995;4:191-3.

17. Brasil J, Opromolla DVA, Souza-Freitas JAS, Rossi JES. Estudo histológico e baciloscópico de lesões lepróticas da mucosa bucal. Estomat Cult 1973;7:113-9.

18. Scollard DM, Skinsnes OK. Oropharyngeal leprosy in art, history, and medicine. Oral Surg Oral Med Oral Pathol Oral Radiol Endod 1999;87:463-70

19. Brand PW. Temperature variation and leprosy deformity. Int J Lepr 1959;27:1-7. 